\title{
Przestrzenne zróżnicowanie wielkopowierzchniowych sieci handlowych w województwie dolnośląskim i jego uwarunkowania
}

Mimo znacznego przyrostu powierzchni w centrach handlowych w Polsce w ostatnich latach, potencjał ich rozwoju jest nadal znaczny. Nasilające się w 2009 r. spowolnienie gospodarcze w Polsce, będące efektem kryzysu finansowego na świecie, skutkuje z jednej strony pogarszaniem się nastrojów i sytuacji dochodowej gospodarstw domowych, z drugiej zaś ograniczeniami w dostępności inwestorów do kredytu. Ich efektem najpewniej będzie weryfikacja części planów inwestycyjnych związanych z rozwojem sieci i centrów handlowych. W sytuacji kryzysowej w lepszym położeniu znajdują się placówki handlowe oferujące towary z segmentu podstawowego i popularnego, z tzw. niższej półki cenowej.

Rynek centrów handlowych i sieci obiektów wielkopowierzchniowych ma charakter rozwojowy, gdyż jest ważnym najemcą i inwestorem. Jego rozwojowi w Polsce sprzyja popularność zakupów w dużych obiektach handlowych, zainteresowanie inwestorów zagranicznych nowymi przedsięwzięciami, przewidywana w następnych latach stabilizacja ekonomiczna i dynamiczny rozwój polskiej gospodarki (Rynek centrów handlowych w Polsce... 2005). W obecnej, kryzysowej sytuacji gospodarczej moga jednak nastapić opóźnienia w otwarciu obiektów handlowych, wstrzymanie realizacji w niektórych lokalizacjach, czy przełożenie projektów inwestycyjnych na okres późniejszy.

\section{Obiekt wielkopowierzchniowy i nowoczesna powierzchnia handlowa}

Współcześnie handel realizowany poprzez wielkopowierzchniowe sieci handlowe utożsamiany jest z tzw. nowoczesną powierzchnią handlową. Głównymi kryteriami służącymi wyodrębnianiu wielkopowierzchniowych, nowoczesnych obiektów handlowych są wielkość zajmowanej powierzchni i asortyment oferowanych artykułów (Sieci i centra handlowe... 2009).

Najczęstszą formą wielkopowierzchniowych, nowoczesnych obiektów handlowych są centra handlowe definiowane jako zgrupowanie punktów handlowych tworzących całość pod względem architektonicznym, administracyjnym i funkcjonalnym. Cały obiekt obejmuje powierzchnię powyżej $5000 \mathrm{~m}^{2}$, a powierzchnia sprzedażowa przynajmniej jednego punktu handlowego przekracza $300 \mathrm{~m}^{2}$. Szczególnymi kategoriami centrów handlowych są:

- wielofunkcyjne galerie handlowe, obejmujące placówki handlowe i gastronomiczne w obiektach nowych lub rewitalizowanych;

- parki handlowe (retail park), będące zespołami wielkopowierzchniowych (pow. $500 \mathrm{~m}^{2}$ ), wolnostojących obiektów zgrupowanych na jednym obszarze, posiadających formułę centrum otwartego, tzn. każdy sklep ma oddzielne wejście. Tworzy go kilku dużych najemców (produkty AGD, elektroniczne, sklepy typu „dom i ogród”, odzieżowe) oraz szereg mniejszych. Klient udaje się do parku handlowego w celu dokonania zakupu konkretnych produktów. Parki handlowe nie służą za miejsca rozrywki i spędzania czasu wolnego. Najczęściej sytuowane są na peryferiach dużych ośrodków miejskich; 
- fabryczne centra wyprzedaży (factory outlet) specjalizujące się w sprzedaży markowych towarów po cenach obniżonych o $30 \%$ do $70 \%$. Są to przeważnie końcówki serii, zapasy magazynowe itp.

Kolejnymi kategoriami nowoczesnych, wielkopowierzchniowych obszarów handlowych są hipermarkety. To sklepy o powierzchni sprzedażowej powyżej $2500 \mathrm{~m}^{2}$ (niejednokrotnie znacznie większe, bo od 8000 do $12000 \mathrm{~m}^{2}$ ), oferujące klientom szeroki asortyment zarówno artykułów spożywczych, jak i przemysłowych (tekstylia, sprzęt RTV-AGD).

Kolejną kategorią, charakteryzującą się znacznie mniejszą powierzchnią sprzedażową, są supermarkety, czyli wielkopowierzchniowe placówki handlowe o powierzchni sprzedażowej od 400 do $2499 \mathrm{~m}^{2}$. Od hipermarketów (oprócz powierzchni sprzedażowej) odróżnia je wachlarz oferowanych produktów. Supermarkety są szczególnie ukierunkowane na sprzedaż produktów spożywczych z niewielkim udziałem artykułów przemysłowych. Mimo to asortyment w tym segmencie sprzedaży w supermarketach jest uboższy niż w hipermarketach.

Podobną kategorię pod względem zajmowanej powierzchni reprezentują sklepy dyskontowe (sklepy o powierzchni od 400 do $2500 \mathrm{~m}^{2}$ ). Charakteryzują się one ograniczoną oferta zarówno artykułów spożywczych, jak i przemysłowych. W dyskontach główny nacisk kładzie się na niskie ceny oferowanych produktów, które uzyskuje się poprzez znaczną redukcję kosztów. Jest to efektem ograniczonej do minimum obsługi klientów, dużego udziału towarów marki własnej (co umożliwia obniżkę kosztów marketingu i opakowań) oraz uproszczonej ekspozycji towarów (wykładane są na półki w opakowaniach zbiorczych, a nie w jednostkowych jak w hiper- czy supermarketach).

Powyższa typologia nowoczesnej, wielkopowierzchniowej placówki handlowej nie ma charakteru jednoznacznego. Przedstawione progi służące identyfikacji poszczególnych jej kategorii są związane ze statystyką GUS, chociaż w instytucji tej spotyka się także bardziej szczegółowe wydzielania (Rynek wewnętrzny... 2008). Firmy doradcze związane z obsługą nieruchomości zaliczają centra handlowe, galerie handlowe i hipermarkety do nowoczesnej powierzchni handlowej, jeśli zajmują one minimum 5000 lub nawet $10000 \mathrm{~m}^{2}$. (Sieci i centra handlowe... 2009).

Istotną rolę w identyfikacji obiektów wielkopowierzchniowych odegrała uchylona ustawa o tworzeniu i działaniu wielkopowierzchniowych obiektów handlowych ${ }^{1}$ (WOH) z 2007 r., w myśl której placówką wielkopowierzchniową jest obiekt handlowy o powierzchni 400 i więcej $\mathrm{m}^{2}$. Powyższe kryterium zostało zastosowane w opracowaniu do identyfikacji wielkopowierzchniowych sieci handlowych na obszarze województwa dolnośląskiego. Badanie sieci sklepów wielkopowierzchniowych w ujęciu lokalnym jest utrudnione z uwagi na brak danych statystycznych z uwzględnieniem kategorii placówek handlowych z poszczególnych lat. Większość operatorów handlowych nie prowadzi tego rodzaju statystyk lub ich nie udostępnia. Dlatego podstawowym źródłem informacji są strony internetowe sieci handlowych, które zawierają dane o aktualnej sieci sklepów. Dane zebrane na potrzeby opracowania przedstawiają stan na 30 czerwca 2009 r.

Z uwagi na konieczność prezentacji badanego zjawiska w ujęciu syntetycznym do agregacji poszczególnych kategorii wielkopowierzchniowych obiektów handlowych wykorzystano kryterium sprzedażowe. Grupuje ono wskazane powyżej placówki handlowe według określonej grupy docelowej odbiorców, do których skierowane są oferty produktów adekwatne do ich potrzeb. Wyróżniamy wielkopowierzchniowe placówki o profilu spożywczo-przemysłowym

${ }^{1}$ DzU 2007, nr 127, poz. 880. 
(grupujące sklepy dyskontowe, supermarkety, hipermarkety) oraz specjalistycznym (np. typu „dom i ogród”, RTV-AGD, grupujące również odpowiednio supermarkety i hipermarkety).

\section{Wybrane uwarunkowania rozwoju wielkopowierzchniowych sieci handlowych w Polsce}

Istotną rolę w tworzeniu warunków dla funkcjonowania wielkopowierzchniowych sieci handlowych odgrywają regulacje prawne. Lokalizację wspomnianych placówek reguluje ustawa o planowaniu i zagospodarowaniu przestrzennym² z 2003 r. Nakłada ona na władze gminy obowiązek określenia w studium uwarunkowań i kierunków zagospodarowania przestrzennego gminy, jak również w planie miejscowym, obszarów rozmieszczenia obiektów handlowych o powierzchni sprzedaży powyżej $2000 \mathrm{~m}^{2}$. Niestety, nadal nie ma ostatecznych rozwiązań legislacyjnych w postaci nowelizacji ustawy o planowaniu przestrzennym.

Ważną rolę dla analizowanego rynku pełniła także ustawa o tworzeniu i działaniu wielkopowierzchniowych obiektów handlowych z 2007 r. Została ona jednak uchylona po wyroku Trybunału Konstytucyjnego ${ }^{3}$ z 2008 r. Jej zasadniczym celem było ograniczenie budowy supermarketów w Polsce. Zgodnie z uchyloną ustawą utworzenie sklepu o powierzchni sprzedaży od 400 do $2000 \mathrm{~m}^{2}$ wymagało zezwolenia gminy, a powyżej $2000 \mathrm{~m}^{2}$ - zezwolenia gminy i sejmiku wojewódzkiego. Jednak główną przyczyną zablokowania na pewien czas budowy dużych obiektów handlowych był brak odpowiednich przepisów wykonawczych.

Dla części dużych operatorów sieciowych i inwestorów z tego segmentu rynku wspomniana ustawa stała się przyczyną reorientacji strategii działania. Zwiększyli oni swoje zainteresowanie mniejszymi ośrodkami miejskimi, budując w nich sieci placówek o mniejszej powierzchni sprzedażowej zamiast kilku dużych obiektów handlowych w największych miastach Polski. W efekcie wielkopowierzchniowe sieci handlowe stały się znaczącą konkurencją dla małych sklepów na rynku lokalnym i spowodowały konieczność ich konsolidacji w układy sieciowe (np. Stokrotka, POLOmarket).

Rynek handlu w Polsce, szczególnie spożywczego, jest jednym z najbardziej rozproszonych w Europie. Nowoczesny handel bazujący na sieci sklepów wielkopowierzchniowych kontroluje jedynie 1/3 polskiego handlu detalicznego. Można z tego wnioskować, że handel tradycyjny nie zanika. Staje się bardziej nowoczesny i zorganizowany w sieci. Rynek jest rozproszony, ale coraz częściej uwidacznia się proces jego konsolidacji przez przyłączanie się małych sklepów do sieci franczyzowych. Jego efektem w dłuższej perspektywie czasowej będzie jednak zmniejszanie się liczby małych sklepów na polskim rynku.

Wpływ na stosunkowo wolne tempo tego procesu mają zachowania konsumenckie Polaków. Badania wskazują, iż Polacy najczęściej spośród innych krajów Europy Środkowo-Wschodniej preferują zakupy w mniejszych sklepach. Stąd udział małych sklepów spożywczych w wartości sprzedaży artykułów spożywczych pozostaje nadal na wysokim poziomie, osiagając w 2008 r. 55\% (Sieci i centra handlowe... 2009). Dodatkowo z badań wynika, że spowolnienie gospodarcze i prawdopodobny wzrost bezrobocia będą przyczyniać się do pewnego zahamowania zjawiska zmniejszania się liczby małych sklepów, które postrzegane są jako sposób na przetrzymanie trudnej sytuacji na rynku pracy.

Korzystne uwarunkowania rozwoju handlu tradycyjnego i nowoczesnego, wielkopowierzchniowego tworzy struktura spożycia indywidualnego gospodarstw domowych w Polsce. Żywność i napoje bezalkoholowe stanowią ponad 26\% ogólnego spożycia indywidualnego (udział wydatków na żywność i napoje bezalkoholowe w Polsce w 2007 r. był wyższy niż

\footnotetext{
${ }^{2}$ DzU 2003, nr 80, poz. 717, z poźn. zm.

${ }^{3}$ DzU 2008, nr 123, poz. 803.
} 
w krajach Unii Europejskiej - uwzględniając 25 państw UE) (Rynek wewnętrzny... 2008). Ponadto obserwowany w Polsce w 2009 r. proces spowolnienia gospodarczego powoduje, że popyt konsumpcyjny staje się głównym czynnikiem wzrostu gospodarczego i może sprzyjać tworzeniu dalszych korzystnych perspektyw także dla rozwoju sieci i centrów o wielkopowierzchniowym charakterze. Kolejnym sprzyjającym rozwojowi tych sieci handlowych w Polsce uwarunkowaniem jest wielkość polskiego rynku detalicznego. Jego wartość i dynamika po okresie spadku z 192 mld zł w 2003 r. do 187 mld zł w 2005 r. sukcesywnie wzrasta z 189 mld zł w 2006 r. do 217 mld zł w 2008 r. Pomimo rysującego się spowolnienia gospodarczego przewiduje się dalszy wzrost również w 2009 r. do wysokości 225 mld zł (szerzej: Spożywczy handel detaliczny... 2009). Należy jednak pamiętać, że istotnym skutkiem wspomnianego spowolnienia gospodarczego może być pogarszająca się sytuacja na rynku pracy, a w jej wyniku obniżające się dochody społeczeństwa. To natomiast może przyczyniać się do tworzenia bardziej sprzyjających warunków rozwoju handlu wielkopowierzchniowego, szczególnie w postaci supermarketów i sklepów dyskontowych, niż tradycyjnego. Tym bardziej, że głównym asortymentem supermarketów i sklepów dyskontowych są produkty spożywczo-przemysłowe, a więc podstawowe i często dostępne po cenach niższych niż w handlu tradycyjnym. Wobec spadku dochodów gospodarstw domowych sklepy dyskontowe i supermarkety mogą być tą formą nowoczesnego handlu, który zyska najwięcej. Utrzymywanie się w dłuższym okresie spowolnienia gospodarczego będzie czynnikiem negatywnym w przewidywaniach zachowań konsumpcyjnych ludności, co utrudni rozwój także handlu nowoczesnego.

Ryc. 1. Rozwój supermarketów spożywczych w Polsce w latach 2003-2008

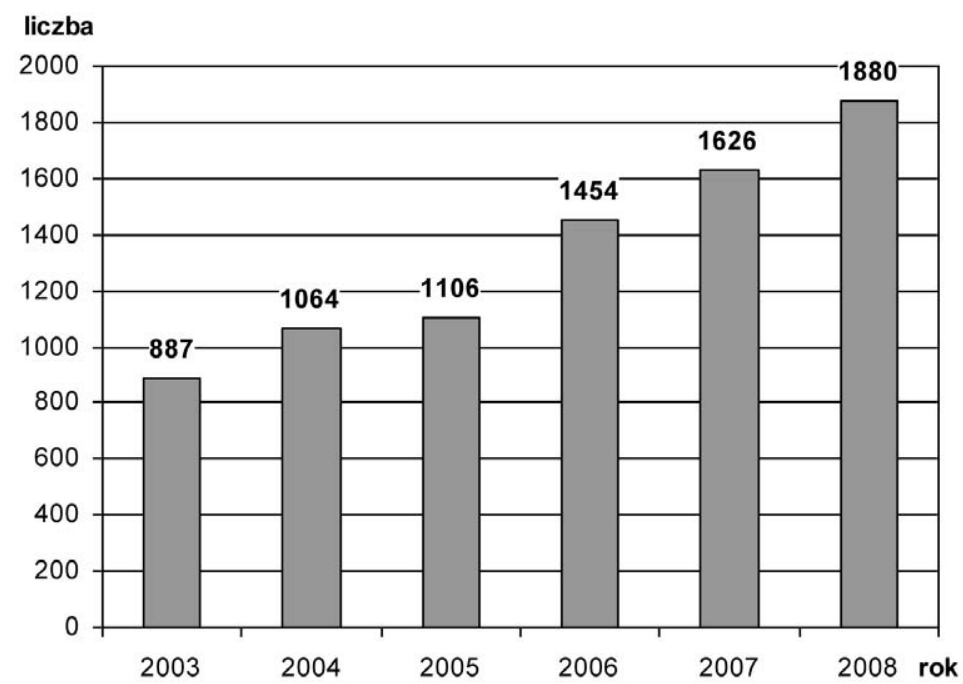

Źródło: opracowanie własne na podstawie „Detal Dzisiaj” (2008).

Obecnie supermarkety i sklepy dyskontowe są najbardziej konkurencyjnym segmentem handlu detalicznego w Polsce. Wraz z upowszechnieniem się sieci supermarketów w średnich i małych miastach ta forma nowoczesnego wielkopowierzchniowego handlu coraz częściej zaspokaja potrzeby lokalne klientów. Rynek supermarketów ulega ciągłym i dynamicznym zmianom (ryc. 1). W okresie od 2003 do 2008 r. ich liczba zwiększyła się ponad dwukrotnie, z 887 w 2003 do 1880 w 2008 roku. Podobną liczebność osiagnęły także sklepy dyskontowe 
(w 2008 r. ponad 1800 placówek). Szacuje się, że w ciągu dwóch kolejnych lat ich liczba w Polsce wzrośnie do 2,5 tysiąca (Sieci i centra handlowe... 2009).

Ryc. 2. Liczba hipermarketów przypadających na milion mieszkańców w wybranych krajach europejskich

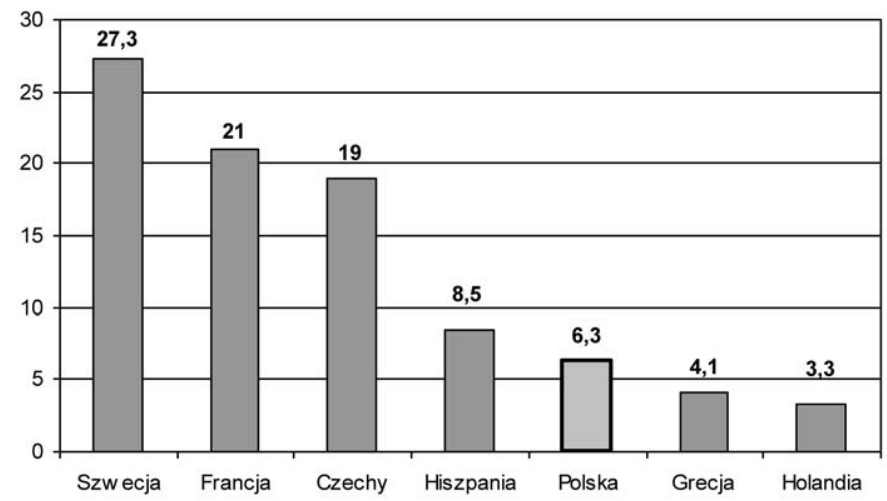

Źródło: opracowanie własne na podstawie Sieci i centra handlowe w latach 2008-2009.

Tendencja wzrostowa ma również miejsce w wypadku hipermarketów. Dynamiczny rozwój sieci wielkopowierzchniowych obiektów handlowych wynika z dotychczasowego niskiego poziomu nasycenia polskiego rynku tą formą handlu. W Polsce na milion mieszkańców przypada tylko kilka hipermarketów, podczas gdy np. w Czechach jest ich trzy razy więcej. Pod tym względem europejskimi rekordzistami są Szwecja czy Francja, z ponad 20 sklepami tego typu na milion mieszkańców (ryc. 2). Podobnie jest w wypadku sklepów dyskontowych. W Polsce na milion mieszkańców przypada 48 tego typu placówek. Zdecydowanie więcej jest ich na przykład w Norwegii (253), Austrii (134) czy Danii (128). Zmieniają się również uwarunkowania lokalizacji sklepów dyskontowych w zakresie wymaganej liczby klientów zapewniających im zadowalające wskaźniki rentowności, z 20 tys. mieszkańców do nawet 8 tys. (Sieci i centra handlowe... 2009), co sprzyja coraz częstszemu ich lokalizowaniu w małych miastach.

\section{Przestrzenne rozmieszczenie wielkopowierzchniowych sieci handlowych na obszarze województwa dolnośląskiego}

Województwo dolnośląskie należy do regionów cieszących się dużym zainteresowaniem wśród operatorów sieci wielkopowierzchniowych obiektów handlowych. Pod względem liczebności tego typu sklepów województwo zajęło w 2007 r. wysoką, bo czwartą pozycję w kraju (8,1\% ogólnej liczby sklepów wielkopowierzchniowych w Polsce), po województwach: śląskim (13,1\%), mazowieckim (12\%), wielkopolskim $(9,3 \%)$, a przed małopolskim $(7,3 \%)$ i łódzkim (6,3\%). Najmniejszy udział w badanej zbiorowości sklepów był charakterystyczny dla województw: opolskiego, podlaskiego i świętokrzyskiego, i kształtował się na poziomie od $3,2 \%$ do $2,4 \%$.

Rozpatrując udział województwa w ogólnej liczbie sklepów w kraju w poszczególnych kategoriach wielkościowych, należy zauważyć, że jego pozycja wzrasta wraz z wielkością powierzchni sprzedażowej. W przedziale 400-999 $\mathrm{m}^{2}$ region dolnośląski zajmował w 2007 r. piątą pozycję w kraju po województwach: śląskim, mazowieckim, wielkopolskim oraz małopolskim. W grupie sklepów o powierzchni 1000-1999 m² województwo zajmowało już 
pozycję czwartą, wyprzedzając województwo małopolskie. Na trzeciej pozycji znalazło się natomiast pod względem liczebności sklepów o największej powierzchni sprzedażowej, czyli powyżej $2000 \mathrm{~m}^{2}$, po województwie mazowieckim i śląskim, a przed wielkopolskim (ryc. 3).

Ryc. 3. Struktura sklepów wielkopowierzchniowych w województwach w 2007 r. według wielkości powierzchni sprzedażowej

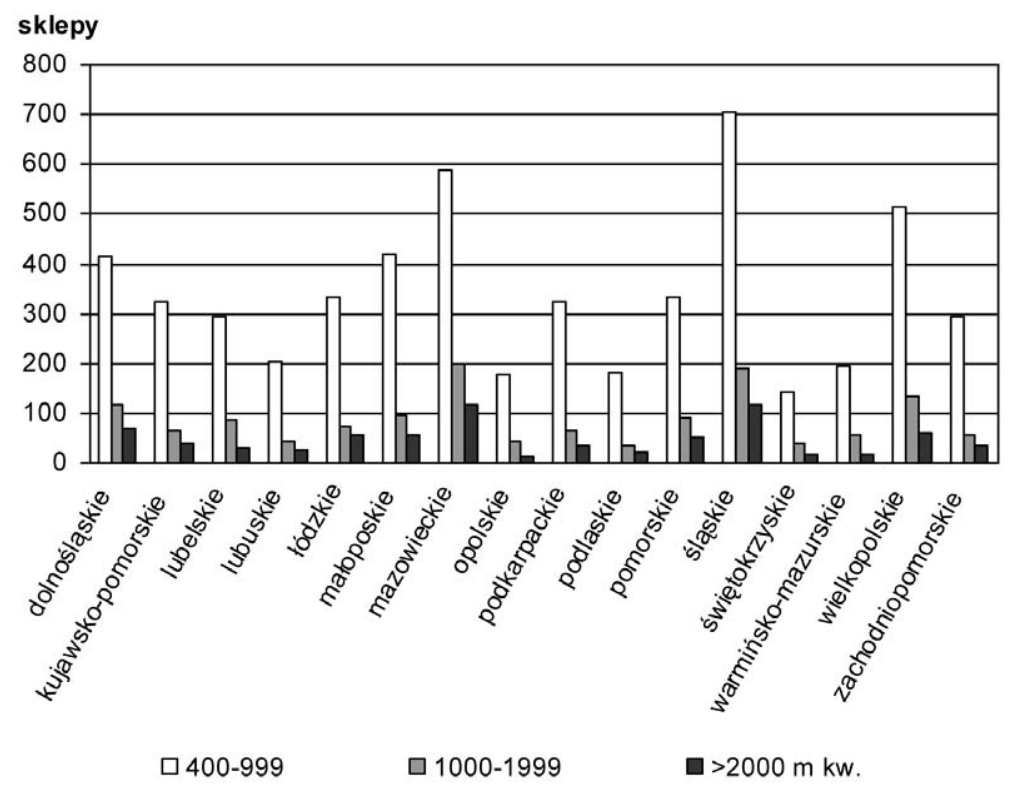

Źródło: opracowanie własne na podstawie Rynek wewnętrzny w 2007 r.

Ryc. 4. Dostępność sieci sklepów wielkopowierzchniowych w Polsce w 2007 r.

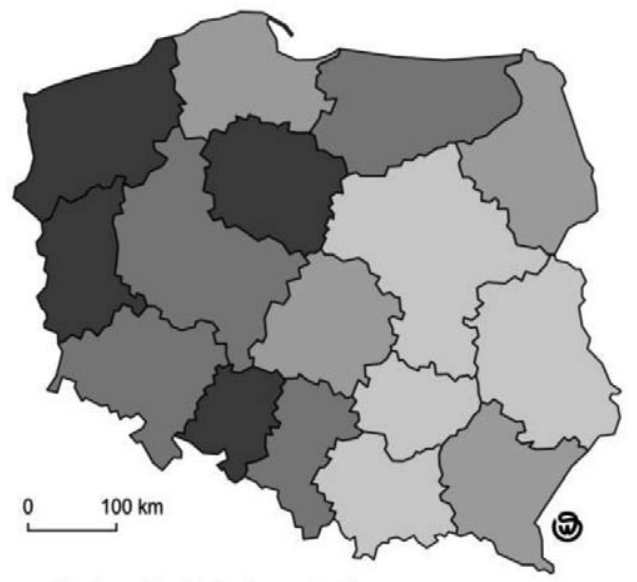

Liczba mieszkańców na 1 sklep

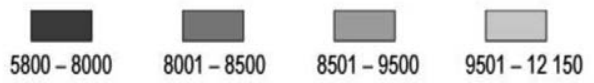

Źródło: opracowanie własne na podstawie Rynek wewnętrzny w 2007 r. i Rocznik Statystyczny Województw 2008. 
Województwo dolnośląskie należy do regionów o wysokiej dostępności wielkopowierzchniowych obiektów handlowych. Pod względem wskaźnika dostępności (liczba osób przypadających na jedną placówkę handlu wielkopowierzchniowego) z wynikiem 8131 osób znalazło się na piątej pozycji po województwie lubuskim, zachodniopomorskim, opolskim i kujawsko-pomorskim, a przed śląskim, wielkopolskim, czy mazowieckim (ryc. 4). Analizowane województwo charakteryzuje się więc najwyższą dostępnością tego typu handlu spośród województw powszechnie uważanych za najbardziej rozwinięte pod względem społeczno-gospodarczym.

W odniesieniu do gęstości placówek wielkopowierzchniowych (liczba sklepów na $100 \mathrm{~km}^{2}$ ), region dolnośląski uzyskuje najkorzystniejsze wartości obok województw śląskiego i małopolskiego (ryc. 5). Analizowane wskaźniki pozwalają zauważyć występowanie pewnych prawidłowości przestrzennych determinowanych gęstością zaludnienia, czyli związanych z liczbą ludności i powierzchnią województwa. Jednostki charakteryzujące się stosunkowo dużą gęstością zaludnienia uzyskują wysokie wartości wskaźnika gęstości sklepów (szczególnie województwo małopolskie oraz śląskie, czy dolnośląskie). Natomiast w tych jednostkach, w których gęstość zaludnienia jest zdecydowanie mniejsza, wartości wskaźnika dostępności są korzystniejsze (szczególnie województwa: lubuskie, zachodniopomorskie, czy warmińsko-mazurskie). Województwa: świętokrzyskie i lubelskie uzyskują natomiast najmniej korzystne wartości, zarówno w zakresie wskaźnika dostępności, jak i gęstości, co świadczy o najniższym poziomie rozwoju wielkopowierzchniowych sieci handlowych na ich obszarze w Polsce (por. ryc. 4 i 5).

Ryc. 5. Gęstość sieci sklepów wielkopowierzchniowych w Polsce w 2007 r.

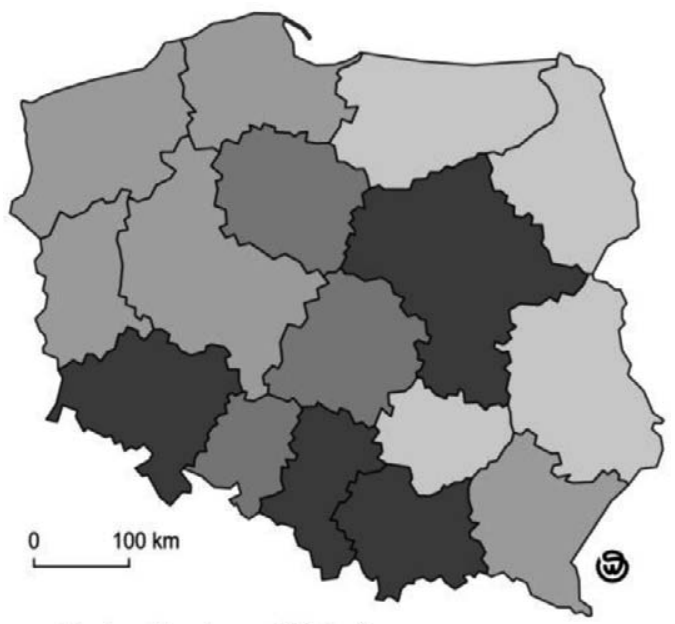

Liczba sklepów na $100 \mathrm{~km}^{2}$

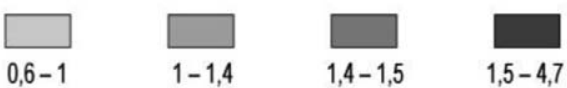

Źródło: opracowanie własne na podstawie Rynek wewnętrzny w 2007 r. i Rocznik Statystyczny Województw 2008. 
Ryc. 6. Dostępność sieci sklepów wielkopowierzchniowych w województwie dolnośląskim w 2009 r.

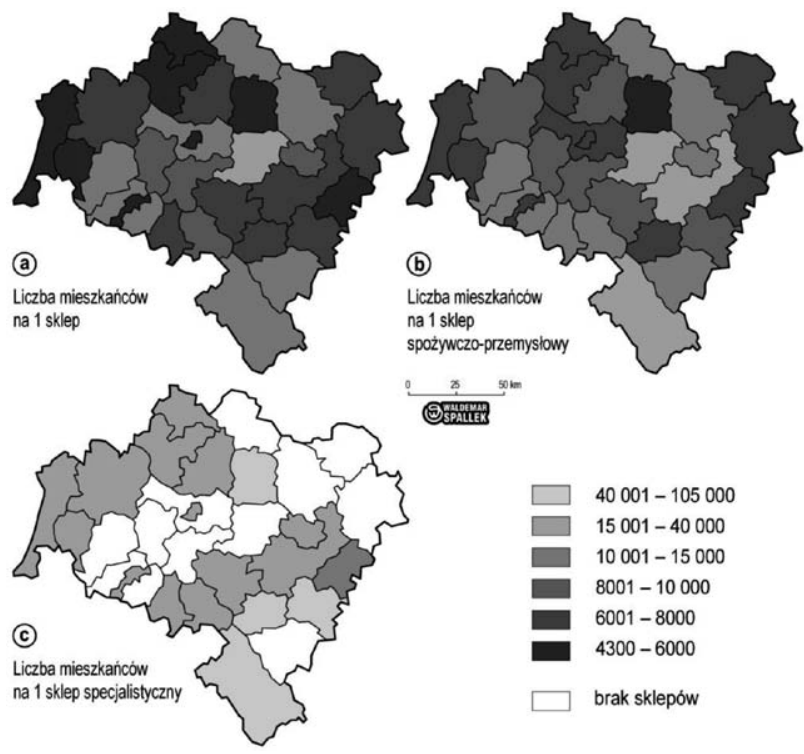

Źródło: opracowanie własne na podstawie stron internetowych sieci handlowych (2009) i Województwo dolnośląskie. Podregiony, powiaty, gminy w 2008.

Na obszarze województwa istnieją znaczne przestrzenne różnice rozmieszczenia wielkopowierzchniowych obiektów handlowych. Najlepsza dostępność jest charakterystyczna dla miast na prawach powiatu: Legnicy i Jeleniej Góry oraz północno-zachodniej części województwa, która obejmuje trzy powiaty zachodnie (zgorzelecki, bolesławiecki i lubański) oraz pas powiatów od głogowskiego, przez polkowicki, lubiński, po wołowski (ryc. 6a). Wysoka wartość wskaźnika dostępności w powiatach zachodnich jest spowodowana bliskością granicy polsko-niemieckiej, która przyczynia się do zwiększenia liczby klientów powyżej poziomu wynikającego z liczby mieszkańców. Powiaty, w których funkcjonują liczne podmioty związane z KGHM, charakteryzują się korzystną sytuacją gospodarczą i dochodową mieszkańców, wpływającą na zwiększanie się chłonności lokalnych rynków.

Nieco niższa dostępność wielkopowierzchniowych sieci handlowych występuje we wschodniej i środkowej części województwa, obejmując powiaty związane z aglomeracją wrocławską (milicki, oleśnicki, wrocławski i oławski) oraz powiaty o znacznej koncentracji ludności: dzierżoniowski i świdnicki.

Najniższe wartości badanego parametru występują w powiatach położonych w pasie przebiegającym z południowego-zachodu (od powiatu jeleniogórskiego i lwóweckiego) na północny-wschód (po powiaty trzebnicki i górowski) oraz na południu regionu (powiaty: kłodzki i ząbkowicki). Są to najczęściej obszary najsłabiej rozwinięte gospodarczo, przeżywające problemy związane z restrukturyzacją lokalnych gospodarek i charakteryzujące się często niskim poziomem urbanizacji. Zwraca uwagę stosunkowo niska wartość wskaźnika dla Wrocławia. Jest to wynikiem bardzo dużej koncentracji ludności, przy której nawet dobrze rozwinięte sieci wielkopowierzchniowych obiektów handlowych nie skutkują wysoką dostępnością, charakterystyczną dla niektórych słabiej zaludnionych powiatów województwa (np.: wołowskiego, milickiego, strzelińskiego). 
Podobne prawidłowości przestrzenne mają miejsce zarówno w wypadku sieci wielkopowierzchniowych sklepów spożywczo-przemysłowych, jak i specjalistycznych (ryc. 6b i 6c). Wobec powyższego - sklepy specjalistyczne jedynie zwiększają stopień dostępności handlu nowoczesnego (szczególnie powiat wrocławski, oławski), ale nie przyczyniają się do zmniejszania dysproporcji jego występowania na obszarze województwa.

Ryc. 7. Gęstość sieci sklepów wielkopowierzchniowych w województwie dolnośląskim w 2009 r.

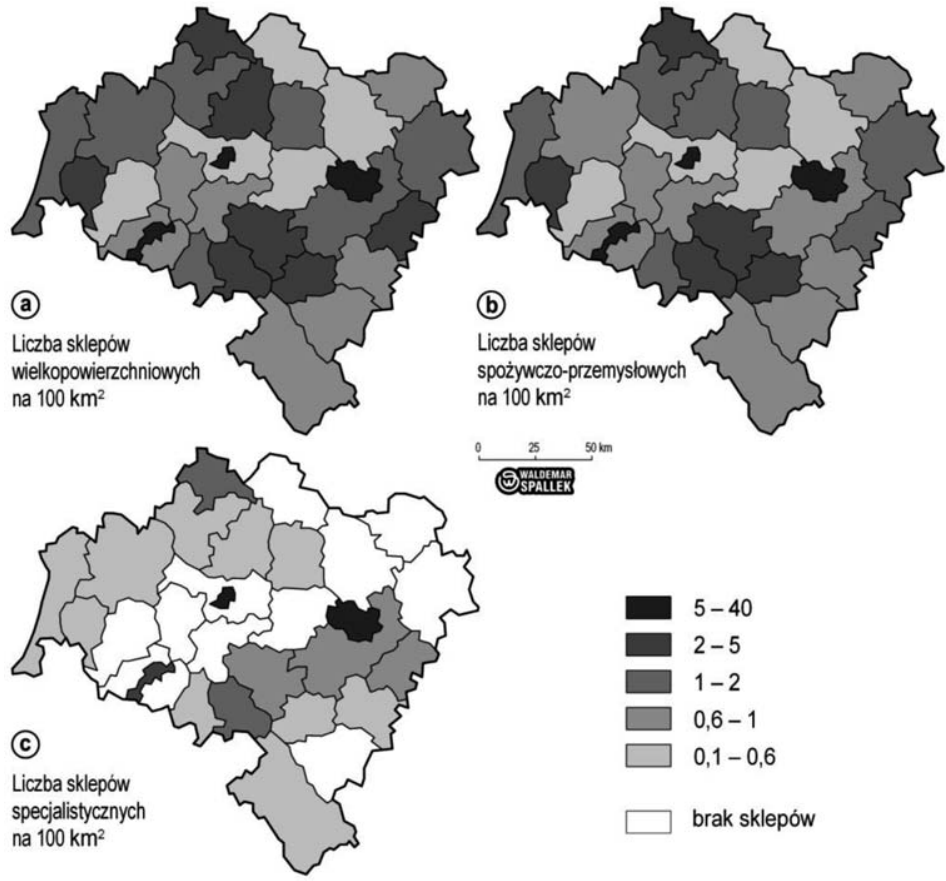

Źródło: opracowanie własne na podstawie stron internetowych sieci handlowych (2009) i Województwo dolnośląskie. Podregiony, powiaty, gminy w 2008.

Podobny układ przestrzenny, ale o odmiennym stopniu nasilenia, dotyczy wskaźnika gęstości wielkopowierzchniowych sieci handlowych (ryc. 7a). Najwyższe wartości występują w miastach na prawach powiatu, w tym także we Wrocławiu, w pasie powiatów we wschodniej i środkowej części województwa (szczególnie powiaty najbardziej zurbanizowane: dzierżoniowski, świdnicki, wałbrzyski i oławski). Obszary te jednocześnie charakteryzują się występowaniem największej liczby tego typu obiektów.

Drugim pasem największej gęstości (podobnie jak w wypadku wskaźnika dostępności) jest północno-zachodnia część województwa związana z silnymi gospodarczo powiatami Legnicko-Głogowskiego Okręgu Miedziowego oraz powiatami przy granicy niemieckiej.

Podobne prawidłowości przestrzenne z niewielkimi modyfikacjami występują w układzie sklepów spożywczo-przemysłowych i specjalistycznych (ryc. 7b i 7c). Istnieje zależność pomiędzy gęstością wielkopowierzchniowych sieci handlowych a gęstością zaludnienia. Wskaźnik korelacji dla wskazanych cech wyniósł 0,9. Zbieżność tych dwóch układów jest więc bardzo silna.

Wobec powyższej zbieżności układów obliczono oczekiwaną, teoretyczną gęstość wielkopowierzchniowych sieci handlowych na podstawie gęstości zaludnienia. W tym celu zastosowano odwzorowanie jednego szeregu w drugi poprzez wyrażenie pierwszego szeregu 
w jednostkach mianowanych drugiego. Ustalono pomiędzy tymi wartościami zależność korelacyjną stosując analizę regresji. Oznaczając gęstość zaludnienia przez G, a oczekiwaną gęstość wielkopowierzchniowych sieci handlowych przez $\mathrm{H}$, równanie regresji możemy zapisać następująco:

$$
\mathrm{H}=\mathrm{a} \times \mathrm{G}+\mathrm{b}
$$

Po obliczeniu współczynników regresji na podstawie danych o gęstości zaludnienia i gęstości wielkopowierzchniowych sieci handlowych w powiatach województwa dolnośląskiego równanie przybiera postać:

$$
\mathrm{H}=0,0161 \times \mathrm{G}-0,1528
$$

Równanie to pozwala dla każdego powiatu przyporządkować gęstości zaludnienia występującej w roli argumentu teoretyczną gęstość wielkopowierzchniowych sieci handlowych w roli funkcji. Tę samą procedurę zastosowano dla dwóch kolejnych grup agregacji wielkopowierzchniowych sieci handlowych:

a) sklepów spożywczo-przemysłowych, gdzie postać wzoru jest następująca:

$$
\mathrm{H}=0,0115 \times \mathrm{G}+0,0601
$$

b) sklepów specjalistycznych o wzorze:

$$
\mathrm{H}=0,0046 \times \mathrm{G}-0,2129
$$

Następnie obliczono różnice pomiędzy rzeczywistą a oczekiwaną gęstością wielkopowierzchniowych sieci handlowych w układzie powiatów.

Ryc. 8. Różnice między rzeczywistą a oczekiwaną gęstością sieci sklepów wielkopowierzchniowych w województwie dolnośląskim w 2009 r.

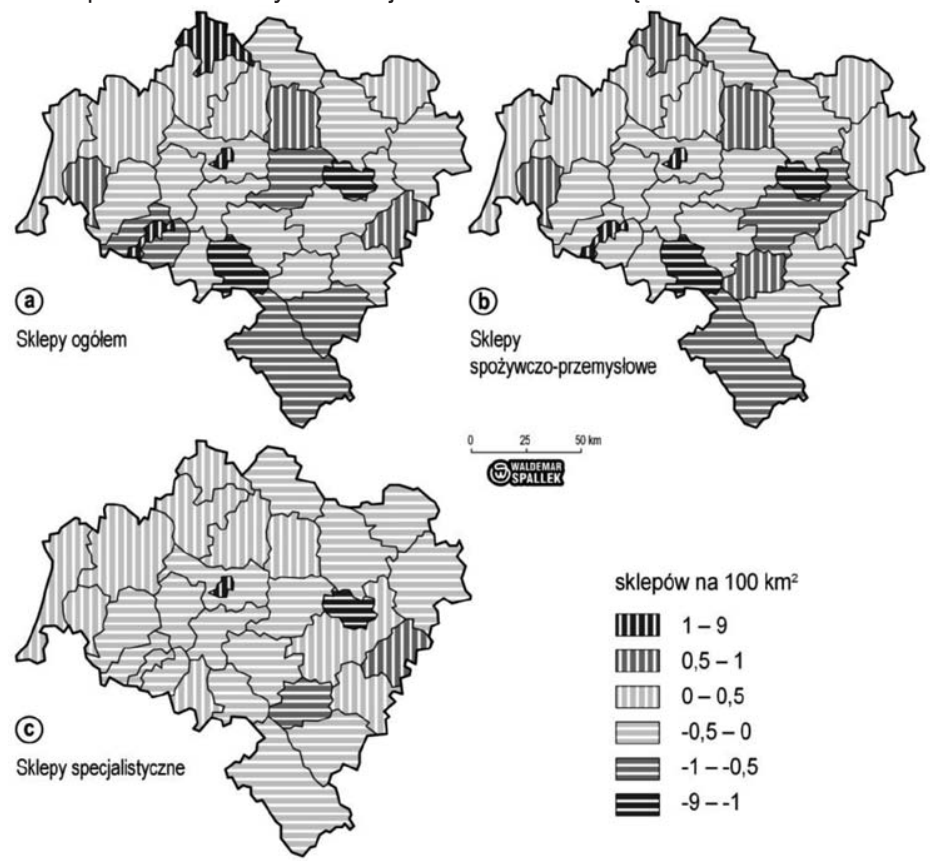

Źródło: opracowanie własne na podstawie stron internetowych sieci handlowych (2009) i Województwo dolnośląskie. Podregiony, powiaty, gminy w 2008. 
Największe odchylenia dodatnie wystąpiły w dwóch miastach na prawach powiatu: Legicy i Jeleniej Górze oraz w powiecie głogowskim (ryc. 8a). Jednostki te charakteryzują się największym w województwie nasyceniem sklepami wielkopowierzchniowymi. Nieco mniejsze odchylenia dodatnie miały miejsce w powiatach: oławskim, wołowskim i lubańskim, a najmniejsze - w powiatach: milickim, polkowickim, lubiński, bolesławieckim i zgorzeleckim. Największe odchylenia ujemne zaobserwowano natomiast w powiecie wałbrzyskim i we Wrocławiu. Powyższe powiaty charakteryzują się najniższą gęstością wielkopowierzchniowych obiektów handlowych w odniesieniu do gęstości zaludnienia w stosunku do pozostałych powiatów regionu. Należy jednak pamiętać, iż są to jednostki o największej koncentracji ludności (szczególnie Wrocław). Nie bez znaczenia pozostaje też trudna sytuacja ekonomiczna powiatu wałbrzyskiego, którego gospodarka ulega ciagłej restrukturyzacji.

W wypadku sklepów spożywczo-przemysłowych zwiększa się liczba powiatów z odchyleniami dodatnimi (ryc. 8b). Natomiast najmniejsze odchylenia dodatnie mają miejsce dla wielkopowierzchniowych sklepów specjalistycznych (ryc. 8c). Na uwagę zasługuje miasto Jelenia Góra czy powiat dzierżoniowski, w których istnieje wyraźna nadreprezentacja sklepów spożywczo-przemysłowych w stosunku do specjalistycznych. Z kolei w powiecie wrocławskim odchylenia dodatnie mają miejsce jedynie w wypadku grupy sklepów specjalistycznych. Przyczyną tej prawidłowości są lokalizacje wielkich centrów handlowych, skupiających przede wszystkim tego rodzaju sklepy przy granicy miasta Wrocławia, lecz administracyjnie wchodzące w skład powiatu wrocławskiego (Bielany Wrocławskie, Mirków). Lokalizacje tych centrów handlowych mają wpływ na obniżanie wielkości wskaźnika dostępności i gęstości wielkopowierzchniowych placówek handlowych we Wrocławiu i na jego zwiększanie w powiecie wrocławskim.

Ryc. 9. Koncentracja sklepów wielkopowierzchniowych w województwie dolnośląskim w 2009 r.

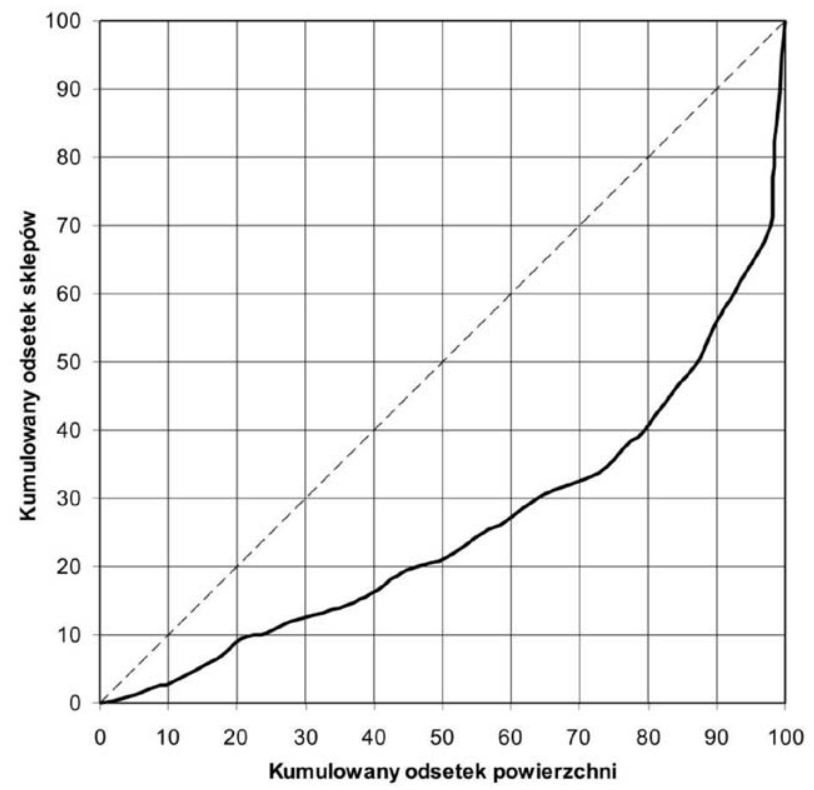

Źródło: opracowanie własne na podstawie stron internetowych sieci handlowych (2009) i Województwo dolnośląskie. Podregiony, powiaty, gminy w 2008. 
Sieci wielkopowierzchniowych obiektów handlowych w województwie wykazują znaczną tendencję do koncentracji. Obliczony wskaźnik koncentracji Lorenza wyniósł 0,47. Z analizy krzywej koncentracji możemy wnioskować, iż na 60\% powierzchni województwa skupia się niespełna 30\% omawianych sklepów. Pozostałe 70\% koncentruje się na znacznie mniejszej powierzchni (ryc. 9). Jest to wynikiem występowania w regionie dużej aglomeracji miejskiej oraz wysokiego poziomu urbanizacji i silnych gospodarczo obszarów charakteryzujących się znaczną chłonnością rynku.

Ryc. 10. Rozmieszczenie spożywczo-przemysłowych sklepów wielkopowierzchniowych na tle gęstości zaludnienia w województwie dolnośląskim w 2009 r.

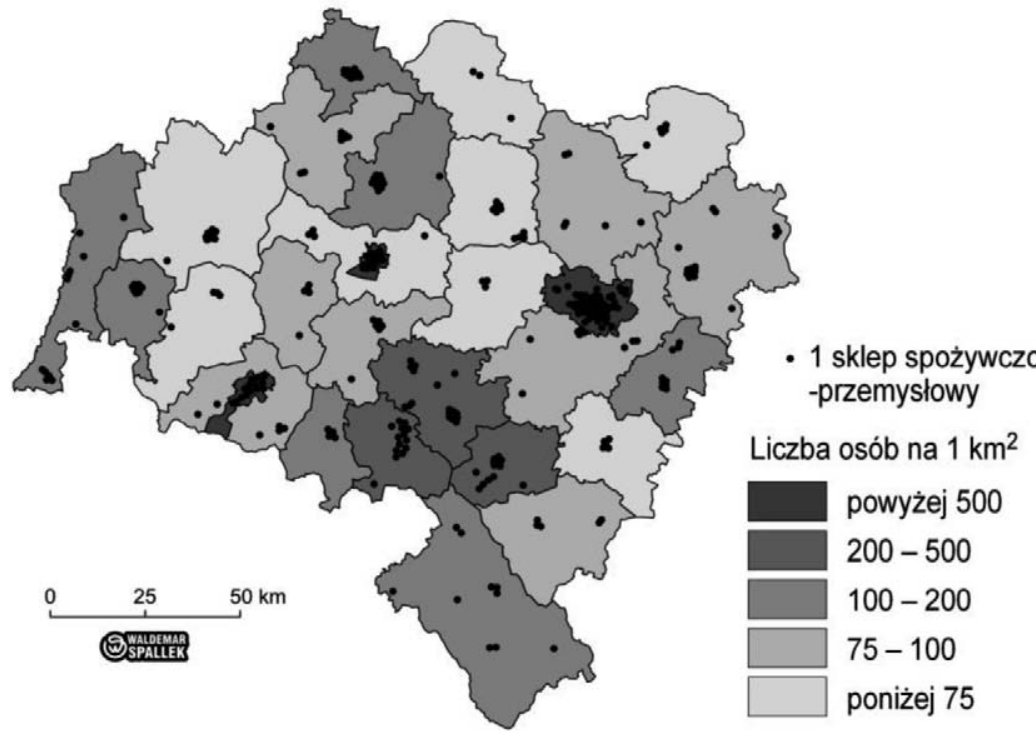

Źródło: opracowanie własne na podstawie stron internetowych sieci handlowych (2009) i Województwo dolnośląskie. Podregiony, powiaty, gminy w 2008.

Wyraźną zależność koncentracji sieci spożywczo-przemysłowych wielkopowierzchniowych obiektów handlowych od gęstości zaludnienia prezentuje ryc. 10. Powiaty o największej gęstości zaludnienia mają największą liczbę analizowanych sklepów. Poziom dostępności sieci w regionie jest już wysoki. Praktycznie od każdego punktu województwa w promieniu 20 km znajduje się wielkopowierzchniowy obiekt handlowy (ryc. 11). Pewien wyjątek stanowią kompleksy leśne w północnej części powiatu bolesławieckiego i wschodniej lwóweckiego, wokół Milicza i Góry oraz typowo rolnicze obszary, znajdujące się na południe i południowy-zachód od Wrocławia.

Omówione wyżej uwarunkowania odgrywają istotną rolę w rozwoju sieci wielkopowierzchniowych obiektów handlowych różnych formatów. Sprzyja temu postępująca zmiana zachowań konsumenckich Polaków, którzy coraz częściej dokonują zakupów w obiektach wielkopowierzchniowych. Równie ważnym czynnikiem jest wielkość polskiego rynku detalicznego, którego wartość i dynamika sukcesywnie wzrastają, pomimo rysującego się spowolnienia gospodarczego. Dynamiczny rozwój sieci wielkopowierzchniowych obiektów handlowych wynika również z dotychczasowego niskiego poziomu nasycenia polskiego rynku tą formą handlu. 
Ryc. 11. Dostępność spożywczo-przemysłowych sklepów wielkopowierzchniowych w województwie dolnośląskim w 2009 r.

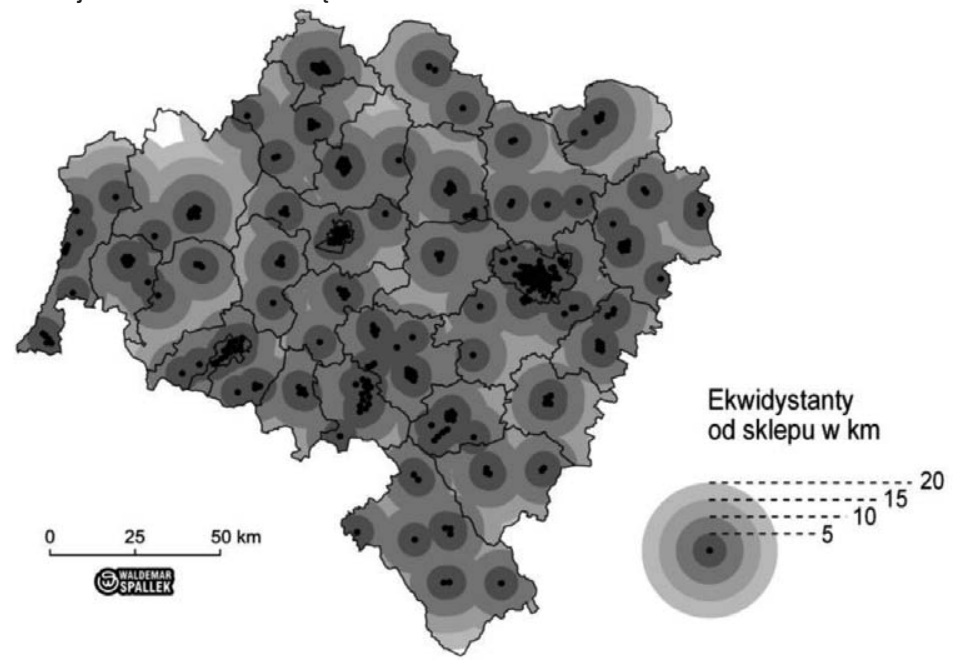

Źródło: opracowanie własne na podstawie stron internetowych sieci handlowych (2009).

Województwo dolnośląskie należy do regionów o najwyższej gęstości sieci sklepów wielkopowierzchniowych. Wartość wskaźnika dostępności jest nieco niższa niż w województwach o najwyższych wartościach wskaźnika, co wynika ze znacznej gęstości zaludnienia.

Istnieje znaczne intraregionalne przestrzenne zróżnicowanie gęstości i dostępności sieci sklepów wielkopowierzchniowych, które wynika z sytuacji społeczno-ekonomicznej regionu. Mimo to, prawie cały obszar województwa znajduje się w obrębie ekwidystanty $20 \mathrm{~km}$ od sklepu wielkopowierzchniowego. Najważniejszymi uwarunkowaniami rozmieszczenia sklepów wielkopowierzchniowych w województwie dolnośląskim są: gęstość zaludnienia, koncentracja ludności (aglomeracje, miasta), poziom rozwoju społeczno-gospodarczego i bliskość granicy polsko-niemieckiej.

\section{Literatura}

1. „Detal Dzisiaj” z dnia 19 listopada 2008, nr 17, Warszawa.

2. Rocznik Statystyczny Województw 2008, GUS, Warszawa.

3. Rynek centrów handlowych w Polsce z uwzględnieniem regionu dolnoślaskiego, 2005, PKO Bank Polski, Departament Strategii, Informacje sektorowe, Warszawa.

4. Rynek wewnętrzny w 2007 r., 2008, GUS, Warszawa.

5. Sieci i centra handlowe w latach 2008-2009, „Wiadomości Gospodarcze”, nr 02-03 (167), Warszawa, s. $1-22$.

6. Spożywczy handel detaliczny w Polsce w dobie kryzysu, 2009, Raport Grocery retail in Poland, 2008, PMR, Warszawa.

7. Ustawa z dn. 27 marca 2003 r. o planowaniu i zagospodarowani przestrzennym, DzU nr 80, poz. $717, \mathrm{z}$ późn. $\mathrm{zm}$.

8. Ustawa z dn. 11 maja 2007 o tworzeniu i działaniu wielko powierzchniowych obiektów handlowych, DzU nr 127, poz. 880.

9. Województwo dolnoślaskie. Podregiony, powiaty, gminy w 2008, Urząd Statystyczny we Wrocławiu. 10. Wyrok Trybunatu Konstytucyjnego z dnia 8 lipca 2008 r. sygn. akt K 46/07, DzU nr 123, poz. 803. 


\section{Spatial Diversification and its Conditioning of Networks of Large Retail Areas in Dolnośląskie Voivodeship}

This paper deals with the spatial diversity of modern channels of retail trade represented by large shops (such as hypermarkets, supermarkets and discount shops) in the Dolnośląskie Voivodeship. This is presented against the background of the main changes to which Polish retail trade has been subjected in recent years.

Despite the dynamic growth of a large retail network in Poland, the internal trade market, especially that of the grocery market, is one of the most fragmented in Europe. This still developing market is where the processes of consolidation and creation of complex networks of large shops will take place in the near future. Changing consumer preferences in favour of modern commercial buildings, but also the investment of foreign and, increasingly, Polish capital have led to this situation.

The article sets out the conditions of distribution of large retail areas in the Dolnoślaskie Voivodeship, which are: population density, the concentration of population (urban areas, cities), level of socio-economic development and the proximity of the German-Polish border. It shows the position of the Dolnośląskie region alongside the rest of the country within the parameters of the research. The Dolnośląskie Voivodeship is a region with a high density of retail space. Its accessibility ratio's value is slightly lower than in those provinces with the highest values of the index, as a result of its higher population density. 